\title{
Ovum Pick Up: Cows Treated With Single Doses of Follicle Stimulating Hormone
}

\author{
Bárbara Letícia Marchi da Silva ${ }^{1}$, Paulo Roberto Adona ${ }^{1}$, Samuel Guemra ${ }^{1}$, Paulo Sergio Monzani ${ }^{2}$ \\ $\&$ Moysés dos Santos Miranda ${ }^{3}$ \\ ${ }^{1}$ Saúde e Produção de Ruminantes, Unopar, Arapongas, PR, Brazil \\ ${ }^{2}$ Departamento de Medicina Veterinária, Universidade de São Paulo, Pirassununga, SP, Brazil \\ ${ }^{3}$ LabTronVet-Medicina Veterinária, Universidade Federal do Pará, Castanhal, PA, Brazil \\ Correspondence: Paulo Roberto Adona, Saúde e Produção de Ruminantes, Unopar, Arapongas, PR, 6702-670, \\ Brazil. Tel: 43-3172-7564.E-mail: paulo_adona@yahoo.com.br
}

\author{
Received: April 8, $2019 \quad$ Accepted: May 18, $2019 \quad$ Online Published: July 15, 2019 \\ doi:10.5539/jas.v11n10p231 URL: https://doi.org/10.5539/jas.v11n10p231
}

\begin{abstract}
Cows treated with single doses of follicle stimulating hormone (FSH) and ovum pick up (OPU) after 24 hours were evaluated for oocyte recovery, in vitro production of embryos (IVPE), and transferred embryos. To begin evaluations, the ovarian follicles larger than three millimeters in diameters were removed from all cows used in the study. Two days after OPU, 200 milligrams of FSH was given in a single dose in 6 cows (treated). Twenty-four hours after application of FSH, the cows underwent a new OPU session for oocyte retrieval. These procedures were repeated three consecutive times without interval. In control (FSH-free) cows the OPU were performed at intervals of one week or oocyte retrieval. The viable oocytes were submitted to IVPE, and the blastocysts were transferred to the recipients. The mean number of oocytes did not differ $(\mathrm{p}>0.05)$ between control cows $(12.1 \pm 2.8)$ and those treated $(10.9 \pm 1.6)$. There were also no differences $(p>0.05)$ in the number $(6.6 \pm 1.7$ and $7.1 \pm 0.9$, respectively) or in the percentage $(54.4 \pm 3.3$ and $64.5 \pm 3.1 \%$, respectively) of viable oocytes between control cows and those treated. The percentage of IVPE and pregnancy did not differ $(\mathrm{p}>0.05)$ between control cows $(39.8 \pm 2.6 \%$ and $44.7 \pm 4.8 \%)$ and those treated $(37.8 \pm 2.5 \%$ and $39.5 \pm 4.1 \%)$, respectively. The treatment with single doses of FSH did not significantly alter the evaluated results for oocyte recovery, IVPE and transferred embryos, and, therefore, did not promote significant improvements for the IVPE as a whole.
\end{abstract}

Keywords: embryo, follicle, girolando, oocyte, pregnancy

\section{Introduction}

In bovine, groups of follicles are continuously recruited throughout the reproductive life during ovarian cycles, with the development of two or three dominant follicles per cycle (two or three follicular waves/cycle). However, only a single dominant follicle, develops until ovulation in the last follicular wave, whereas the other follicles gradually become atretic during the follicular growth phase (Baruselli, Gimenes, \& Sales, 2007; Ginther, Siddiqui, Baldrighi, \& Wolf, 2016).

Follicular dominance is associated with a reduction in plasma concentration levels of follicle stimulating hormone; the subordinate follicles interrupt their growth, become atretic, and the recruitment of new follicles is blocked, a fact that reduces the number and quality of the initially recruited follicles (Adams, Jaiswal, Singh, \& Malhi, 2008; Kim et al., 2001). These ovarian events have generated broad interest in the reproductive biotechnology field, which aims to develop hormonal protocols for ovarian stimulation that are able to support follicular growth, in order to prevent follicles from becoming atretic, and to enable the collection of a larger number of oocytes to be used in embryo production in vitro (Khan, Pinaffi, Beg, \& Ginther, 2012).

Follicle stimulating hormone treatment can be used as an alternative to oocyte recovery through ovum pick up in order to minimize negative effects resulting from the settling of the dominant follicle (Ginther, Siddiqui, Baldrighi, \& Araujo, 2017; Goodhand, Watt, Staines, Hutchinson, \& Broadbent, 1999). Follicle stimulating hormone postpones the selection of the dominant follicle, as well as the atresia of the subordinate ones, and it increases the mean diameter of the follicles, making them available for ovum pick up (Ginther et al., 2017). The 
administration of exogenous follicle stimulating hormone allows follicles that would not have been selected through developmental changes to become dominant (Ginther et al., 2017; Lucy, 2007).

Among the reproductive biotechnologies, in vitro embryo production has been considered a very relevant alternative for rapid genetic improvement in cattle (Vieira et al., 2014). The efficiency of in vitro embryo production has been reported as more effective in beef cattle breeds compared to dairy cattle breeds (Ferreira et al., 2011; Gimenes et al., 2015; Ratto, Peralta, Mogollon, Strobel, \& Correa, 2011). Therefore, further research are needed to evaluate procedures to improve the efficiency of vitro embryo production in dairy cattle breeds. The application of protocols for follicular wave synchronization and superstimulation before OPU may be an alternative to improve the efficiency of this biotechnology in dairy breeds.

Hybrid animals mainly result from crossbred between Bos taurus and Bos indicus animals are widely used in tropical and subtropical countries, such as Brazil, which is one of the largest milk producing, with $80 \%$ of milk production comes from crossbred cattle, with an estimated population close to 10 million animals (Cole \& Silva, 2016; Oliveira Junior et al., 2017). In Brazil, most dairy farming systems use the Girolando hybrid cattle (Holstein and Gir), which has shown productivity, rusticity, and thermal adaptations (Alves et al., 2014). The Girolando breed is adapted to the Brazilian tropical climate, characterized by a warm and semi-humid seasonal climate with rainy summers and dry winters (Alves et al., 2014).

The aim of the current study was to investigate oocyte-donor Girolando cows, treated with follicle stimulating hormone in single doses and ovum pick up 24 hours after the application of the hormone, with additional treatments every three days, to assess oocyte recovery, in vitro embryo production, and the percentage of pregnancy after transfer.

\section{Materials and Methods}

The chemicals were acquired from Sigma Chemical Company (Saint Louis, Missouri, United States) unless specified otherwise.

\subsection{Ethics Statement}

All procedures in this experiment were approved by the Committee of University and performed in accordance with animal welfare and ethics ( $\mathrm{n}^{\circ}$ 004/17), following the norms of the Brazilian Council of Control of Animal Experimentation.

\subsection{Location Experiment}

The experiment was carried out in a farm located in the municipality of Tamarana, Paraná, Brazil. Latitude $23^{\circ} 12^{\prime} 22^{\prime \prime}$ South, longitude $51^{\circ} 45^{\prime} 49^{\prime \prime}$ West and altitude of 753 meters. Climate: Subtropical, Cfa-humid temperate with hot summer and precipitation of $1490 \mathrm{~mm}$. Maximum temperature $\left(30.2^{\circ} \mathrm{C}\right.$, mean $\left.28.8^{\circ} \mathrm{C}\right)$ and minimum $\left(6.4^{\circ} \mathrm{C}\right.$, mean $\left.14.4^{\circ} \mathrm{C}\right)$ of the period in which the study was performed.

\subsection{Donors Selection}

Twelve crossbred dairy cows of the Girolando breed (5/8 Holstein and 3/8 Gir) divided into two groups of 6 animals (control and treated) were used as oocyte donors for the experiment. During the experimental period (Ovum pick up), the cows were not pregnant, but were lactating phase and in cyclic follicular phase (corpus luteum). The animals were also selected how age (between 4 and 6 years of age, weighing approximately 450 $\mathrm{kg}$ ), how much follicular population in the ovaries (greater than ten follicles, more than $3 \mathrm{~mm}$ in diameters) and second zootechnical characteristics of the Girolando breed, according to the Genetic improvement program of the Girolando breed (da Silva et al., 2018). The selected donors were kept in pasture of star grass (Cynodon plectostachyus) with access to water and mineral salt ad libitum (obeying the of rational grazing), besides supplementation with corn silage and balanced feed (Table 1). 
Table 1. Composition of ingredients ( $\%$ of dry matter) of supplemental mixture

\begin{tabular}{ll}
\hline Ingredient & Percentage (\%) \\
\hline Corn silage & 49.92 \\
Grass hay (Cynodon plectostachyus) & 8.84 \\
Ground corn & 19.54 \\
Soybean meal & 15.62 \\
Soya grain & 2.52 \\
Wheat meal & 1.03 \\
Mineral mix* & 1.23 \\
Calcitic limestone & 0.47 \\
Urea & 0.14 \\
Sodium bicarbonate & 0.70 \\
\hline
\end{tabular}

Note. *Composition: $183 \mathrm{~g} / \mathrm{kg}(\mathrm{Ca}), 75 \mathrm{~g} / \mathrm{kg}(\mathrm{P}), 81 \mathrm{~g} / \mathrm{kg}(\mathrm{Na}), 25 \mathrm{~kg} / \mathrm{kg}(\mathrm{Mg}), 25 \mathrm{~g} / \mathrm{kg}(\mathrm{S}), 1200 \mathrm{mg} / \mathrm{kg}(\mathrm{Mn}), 50$ $\mathrm{mg} / \mathrm{kg}$ (I), $2500 \mathrm{mg} / \mathrm{kg}(\mathrm{Zn}), 50 \mathrm{mg} / \mathrm{kg}(\mathrm{Co}), 650 \mathrm{mg} / \mathrm{kg}(\mathrm{Cu}), 25 \mathrm{mg} / \mathrm{kg}$ (Se), $1500 \mathrm{mg} / \mathrm{kg}(\mathrm{Fe}), 20 \mathrm{mg} / \mathrm{kg}(\mathrm{Cr})$.

\subsection{Ovum Pick Up (OPU)}

To begin evaluations, the ovarian follicles larger than three millimeters in diameters were removed from the twelve cows. Two days after, in the group of treated cows ( 6 animals) after ovum pick up 200 milligrams (Vieira et al., 2016) of follicle stimulating hormone (Folltropin-V, Bioniche Animal Health Inc. United States) was given intramuscularly in a single dose. Twenty-four hours after application of follicle stimulating hormone, the cows underwent a new ovum pick up session for oocyte retrieval. These procedures were (FSH and OPU) repeated three consecutive times after ovum pick up at baseline. In non-hormone-stimulated animals, OPUs will attempt to be conducted at intervals of one week or longer, so as not to generate a significant reduction in the number of oocytes recovered. However, in procedures performed twice a week, there was a significant reduction in the number of oocytes recovered by OPU (De Roover, Feugang, Bols, Genicot, \& Hanzen, 2008). Based on these strategies the animals of the control group did not receive any type of treatment with hormone and only were submitted to follicular aspiration at intervals of one week, according to the previously standardized ovum pick up technique (Figure 1).

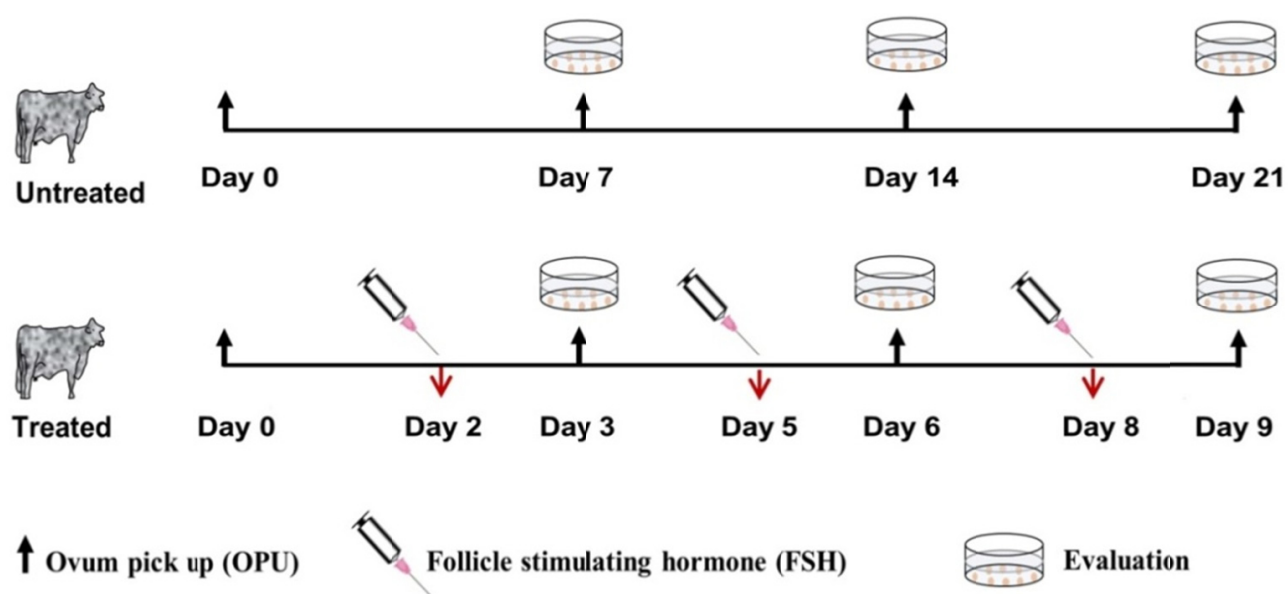

Figure 1. Simplified diagram of experimental design. Consecutive ovum pick up procedures performed on Girolando cows treated with $200 \mathrm{mg}$ of follicle stimulating hormone (treated) or not (untreated)

Follicular aspirations were performed through a convex transducer (Frequency Range: 5-12 Mega-hertz) mounted on an intravaginal device and coupled to the DP-2200Vet ultrasound (Mindray Medical International Ltd. China). The oocytes aspirated during ovum pick up were placed in a $50 \mathrm{~mL}$ polypropylene tube containing $15 \mathrm{~mL}$ phosphate buffered saline with $1 \%$ fetal bovine serum (FBS), $50 \mu \mathrm{g} / \mathrm{mL}$ gentamicin and $10 \mathrm{IU} / \mathrm{mL}$ heparin, the tube was coupled to a vacuum pump BV-003D (Watanabe Technology Applied, Brazil). 


\subsection{Oocyte Selection}

The aspirated oocytes were deposited on a filter and a gridded search dish all-in-one, and washed in phosphate buffered saline with $1 \%$ FBS e serum and $50 \mu \mathrm{g} / \mathrm{mL}$ gentamicin. The classification procedure was performed under a stereomicroscope (Nikon Instruments Inc. United States, SMZ1000), and oocytes were considered viable if they presented one or more compact cumulus cell layers with homogeneous cytoplasm or slight granulation. The oocytes were placed in $1.5 \mathrm{~mL}$ tubes containing $1 \mathrm{~mL}$ of medium $199-\mathrm{H}$ (M7528) with $10 \% \mathrm{FBS}, 50 \mu \mathrm{g} / \mathrm{mL}$ gentamicin, $100 \mu \mathrm{M}$ cysteamine, and $0.2 \mu \mathrm{M}$ pyruvate; the oocytes were placed in a thermos bottle at $36^{\circ} \mathrm{C}$ for $4 \mathrm{~h}$, and sent for in vitro fertilization (Sastre et al., 2014).

\subsection{Maturation in vitro}

Selected oocytes were in vitro matured in medium 199-B (M4530) with $10 \%$ fetal bovine serum, $5.0 \mu \mathrm{g} / \mathrm{mL}$ Lutropin- $\mathrm{V}, 0.5 \mu \mathrm{g} / \mathrm{mL}$ Folltropin- $\mathrm{V}, 50 \mu \mathrm{g} / \mathrm{mL}$ gentamicin, $0.2 \mu \mathrm{M}$ pyruvate, and $100 \mu \mathrm{M}$ cysteamine. Oocytes were cultured for 22 hours in in vitro maturation medium droplets $(100 \mu \mathrm{L})$ under mineral oil on a Petri dish (Corning Incorporated. United States, 430166) at $38.5^{\circ} \mathrm{C}$ under an atmosphere of $5 \%$ carbon dioxide in air and $100 \%$ relative humidity (Rahman, Ibrahim, Osman, Jaffar, \& Osman, 2017)

\subsection{Embryo Production in vitro}

Cryopreserved semen was prepared by density gradient technique using BoviPure and BoviDilute solutions (Nidacon International AB, Sweden). The oocytes were fertilized in fertilization medium (Parrish, 2014) with 2 $\times 10^{6}$ spermatozoa cells $/ \mathrm{mL}$ in a $100 \mu \mathrm{L}$ droplet of medium under mineral oil in a Petri dish, for a period of 18 hours. In vitro culture was performed in synthetic oviduct fluid medium in $100 \mu \mathrm{L}$ droplets with a monolayer of somatic (cumulus) cells (Sovernigo et al., 2017). In vitro culture of embryos was performed at $38.5^{\circ} \mathrm{C}$ and an atmosphere of $5 \%$ carbon dioxide in air. On the seventh day after in vitro fertilization, the percentage of blastocysts was determined on the basis to International Embryo Transfer Society criteria (Wright, 1998).

\subsection{Embryo Transfer and Pregnancy Diagnosis}

The recipients used were Girolando heifers (150 animals aged 24-26 months, with body score of 3.5 on the 1-5 scale, weighing approximately $320 \mathrm{~kg}$ ) in the follicular phase (cyclic) that were synchronized with an intravaginal progesterone implant (Sincrogest) and $2 \mathrm{~mL}$ (intramuscularly) estradiol benzoate (Sincrodiol). The implants were removed on day 8 and animals treated with 300 IU (intramuscularly) Equine Chorionic Gonadotrophin (Novormon), $150 \mathrm{mg}$ (intramuscularly) cloprostenol (Ciosin) and $1 \mathrm{~mL}$ (intramuscularly) estradiol benzoate. Transfers embryos were performed by the nonsurgical transcervical method into the uterine horn, ipsilateral to the corpus luteum of the recipients who responded to estrus synchronization, and that had a corpus luteum of $17 \mathrm{~mm}$ or more in diameter. Pregnancy diagnosis was performed by transrectal ultrasonography 60 days after embryo transfer.

\subsection{Statistical Analysis}

All statistical analyses were performed by using BioEstats 5.3 software (Instituto Mamirauá). The Chi-square $\left(\mathrm{X}^{2}\right)$ test was used to determine the influence of treatment (follicle stimulating hormone) in Girolando donors regarding frequencies of total and viable oocytes, blastocysts, and pregnancy. Results were considered significant at values of $\mathrm{p}<0.05$.

\section{Results and Discussion}

In the present study, Girolando donor dairy cows were used to test the effects of single dose follicle stimulating hormone treatment, followed by ovum pick up after 24 hours of hormonal application. There was no significant difference in the total oocytes recovered between control and follicle stimulating hormone treated cows $(p>0.05$; Table 1), or in the mean number of oocytes recovered (Figure 2) between control cows (mean 12.1 \pm 1.8 ) and

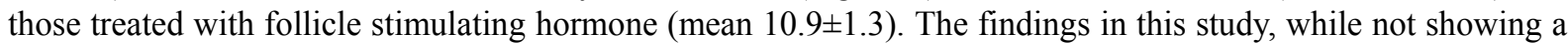
significant increase in the number of total oocytes recovered from donors treated with follicle stimulating hormone, can be used, but with caution, because it is possible to perform several consecutive ovum pick up sessions in short time periods, without significant losses for oocyte recovery. However, previously published studies report contradictory results in the recovery of oocytes with hormonal stimulation before follicular aspiration in cattle (Chaubal et al., 2007; da Silva et al., 2017; Vieira et al., 2016). Disagreements between studies may be the result of different cow breeds, hormonal stimulation protocols, and other factors such as donor age, climate, nutrition, and genetics (Chaubal et al., 2007; da Silva et al., 2017; De Roover et al., 2008; Vieira et al., 2016). 
Table 2. Oocyte recovery, in vitro embryo production, and pregnancy rates in FSH-treated and untreated Girolando cows

\begin{tabular}{|c|c|c|c|c|c|c|}
\hline \multirow{2}{*}{ Treatments } & \multirow{2}{*}{$\begin{array}{l}\text { Total oocytes } \\
\mathrm{N}( \pm \mathrm{SD})\end{array}$} & \multicolumn{2}{|c|}{ Viable oocytes } & \multirow{2}{*}{$\begin{array}{l}\text { Blastocysts }^{1} \\
\mathrm{~N}(\% \pm \mathrm{SD})\end{array}$} & \multirow{2}{*}{$\begin{array}{l}\mathrm{ET}^{2} \\
\mathrm{~N}\end{array}$} & \multirow{2}{*}{$\begin{array}{l}\text { Pregnancy3 } \\
\mathrm{N}(\% \pm \mathrm{SD})\end{array}$} \\
\hline & & $\mathrm{N}( \pm \mathrm{SD})$ & $\%( \pm \mathrm{SD})$ & & & \\
\hline Control cows & $217( \pm 8.4)$ & $118( \pm 5.2)$ & $54.4( \pm 3.3)$ & $47(39.8 \pm 2.6)$ & 47 & $21(44.7 \pm 4.8)$ \\
\hline FSH cows & $197( \pm 4.9)$ & $127( \pm 2.6)$ & $64.5( \pm 3.1)$ & $48(37.8 \pm 2.5)$ & 48 & $19(39.5 \pm 4.1)$ \\
\hline
\end{tabular}

There was no difference between treatments $(\mathrm{p}<0.05)$. Mean percentage $(\%)$ and standard deviation $( \pm$ SD) of the mean from three replicates. ${ }^{1}$ Embryos of class I, seven days post-in vitro fertilization. ${ }^{2}$ Embryo transfer (ET). ${ }^{3}$ Pregnancy: 60 days after embryo transfer.

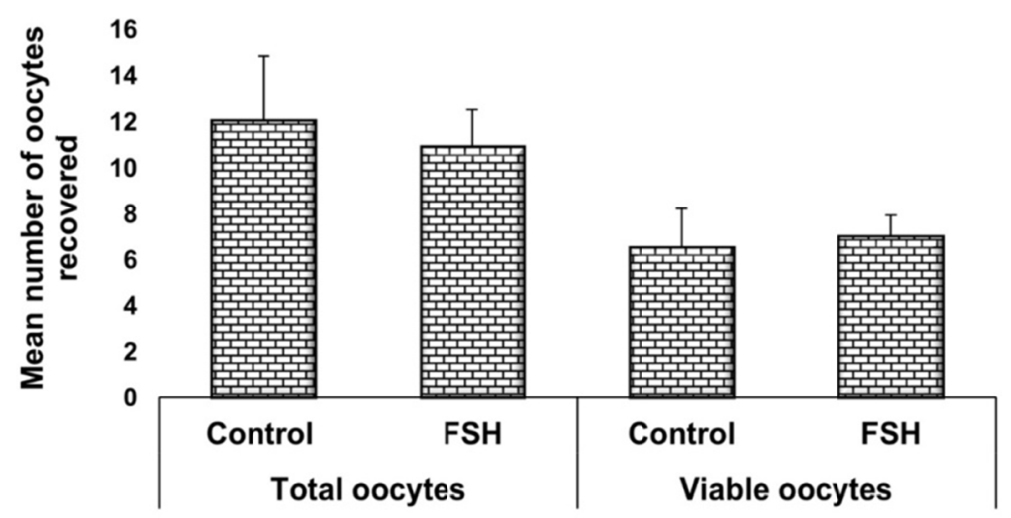

\section{Evaluation of three ovum pick up}

Figure 2. Mean number of total oocytes and mean of viable oocytes recovered in three ovum pick up sessions performed on Girolando cows treated with follicle stimulating hormone (FSH) or not (control)

Despite the differences between the studies in the recovery of oocytes after treatment with follicle stimulating hormone, most of these studies use two or more doses of follicle stimulating hormone on consecutive days, in association with progesterone or other hormones (Goodhand, Staines, Hutchinson, \& Broadbent, 2000; Oliveira et al., 2016; Vieira et al., 2014). These protocols (In general terms: progesterone device, estradiol benzoate and FSH in different administration regimens) are different from, and slightly more laborious than, the one performed in this study that used follicle stimulating hormone in a single dose and ovum pick up 24 hours after the application of the hormone. The protocol described here has not been previously described to the best of our knowledge, but in the study performed by Chaubal et al. (2007), which has some similarities to the present study, oocyte recovery also did not differ significantly between treatment and control groups. However, Vieira et al. (2016) demonstrated an increase in oocyte recovery with follicle stimulating hormone treatment, with some differences in the protocols (follicle stimulating hormone, in association with progesterone, estradiol and hyaluronan) they used compared to ours (only, single dose of follicle stimulating hormone).

The absence of significant effect on the total number of oocytes recovered in lactating Girolando cows may be due to the particularity of the breed or the specific animals evaluated in this study. However, Chaubal et al. (2007) also observed no differences, whereas Vieira et al. (2016) observed differences in oocyte retrieval, but the animals evaluated were Angus and non-lactating Holstein cows, respectively, demonstrating that there is variation among the breeds evaluated for oocyte recovery. Another factor that may have contributed to the similarity of total oocytes recovered was the concentration of follicle stimulating hormone (200 mg), which may not have been ideal for Girolando cattle. According to Baruselli et al. (2006), there are some physiological differences between bovine breeds, which may affect the results of ovarian hyperstimulation: Bos taurus animals are less sensitive to follicle stimulating hormone than Bos indicus (Baruselli et al., 2006).

In terms of the number of viable oocytes selected, there was no significant difference between control and follicle stimulating hormone treated cows $(\mathrm{p}>0.05$; Table 1). In addition, there were no significant differences $(p>0.05)$ between the control and follicle stimulating hormone treated cows for the mean number $(6.6 \pm 1.2$ and $7.1 \pm 1.1$, respectively) or mean percentage of viable oocytes (Table 1; Figure 2). Studies in cattle describe that follicle stimulating hormone is involved in the follicular development and organization of the oocyte cytoplasm, 
determining its quality (da Silva et al., 2017). Although follicle stimulating hormone is involved in oocyte quality, in this study there was no significant increase in the number or percentage of viable oocytes among the Girolando cows we evaluated. This similarity of the percentage of viable oocytes recovered between groups was also identified in other studies, which demonstrated that the rates of viable oocytes recovered did not change significantly even when cow breeds and follicle stimulating hormone application protocols were different from those used in this study (Chaubal et al., 2006; da Silva et al., 2017; Vieira et al., 2014).

The efficiency of the in vitro production of embryos is measured in terms of quality, reflecting the percentage of embryos and of pregnancy. The low efficiency of the in vitro production of embryos has been attributed to the low competence of bovine oocytes from antral follicles submitted to forced in vitro maturation (Merton et al., 2003; Sirard \& Blondin, 1996). However, despite the differences between the groups used for oocyte retrieval in the Girolando cows, the rate of in vitro embryo production of these oocytes was similar $(p>0.05$; Table 1) between cows that had been treated with follicle stimulating hormone and those that had not. These results suggest that the treatment of Girolando cows with follicle stimulating hormone did not significantly $(\mathrm{p}>0.05)$ affect the intrinsic quality of the oocytes, resulting in similar $(\mathrm{p}>0.05)$ in vitro production of embryos in the two groups (Table 1). These results of the in vitro production of embryos are similar to those of other studies in cows of different breeds (da Silva et al., 2017; Ribeiro et al., 2011; Sastre et al., 2014).

According to some studies, another factor that plays a fundamental role in the in vitro production of embryos are cumulus cells linked to the oocyte, which may negatively influence embryo production in vitro (Macaulay et al., 2014; Zhang, Jiang, Wozniak, Yang, \& Godke, 1995). However, in our study the criteria for selection of viable oocytes for in vitro embryo production were the same in treated or control Girolando cows. These oocytes exhibited more than one layer of compact cumulus cells and a homogeneous cytoplasm. Although not subject to study, the similarity among viable oocytes (treated or control cows) submitted to in vitro fertilization was probably responsible (hypothesis) for the similarity in embryo rates in both groups. However, although follicle stimulating hormone is linked to the development of oocytes in vivo and in vitro, in addition to the regulation of somatic cellular functions for follicular development (Sirard, Desrosier, \& Assidi, 2007), in this study and in other studies described in the literature, no significant increase in the in vitro production of embryos was observed in cows treated with follicle stimulating hormone (da Silva et al., 2017; Ribeiro et al., 2011).

Compared with another study in Girolando cows, oocyte recovery was lower in this study, while the percentage of embryos produced in vitro from viable oocytes was higher (Pontes et al., 2010). Nevertheless, The mean percentage of pregnancy (Table 1) of embryos produced in vitro transferred to recipients did not differ significantly $(\mathrm{p}>0.05)$ in this study, and in comparison with the study conducted by Pontes et al. (2010), although the cross-degree of the Girolando animals in this study (5/8) differed from those reported by Pontes et al. $(2010 ; 1 / 4$ and 1/2). The differences between studies may be associated with a wide variety of factors, even in animals of the same breed, such as: effects of heat stress, heifers or cows, and nutrition (Adamiak, Mackie, Watt, Webb, \& Sinclair, 2005; Alves et al., 2014; Vieira et al., 2014). Other factors may also influence the results of in vitro embryo production: Among these factors, it is worth highlighting the quality of the oocytes, which can be affected by a large number of environmental factors, impacting the production of blastocysts and pregnancy (Adamiak et al., 2005; Alves et al., 2014; De Bem et al., 2014).

Oocyte retrieval, mean percentage of in vitro embryo production, and the pregnancy rate in this study are in line with those found in the literature, even in comparison with other studies using different protocols and different breeds for ovarian stimulation (Cavalieri et al., 2017; da Silva et al., 2017; Pontes et al., 2010). The absence of significant variation in the pregnancy rates can be attributed to the similar quality of the embryos (blastocysts, class I) transferred to the recipients. Other studies have also reported similar pregnancy rates in different breeds (Pontes et al., 2010; Sastre et al., 2014; Vieira et al., 2016).

\section{Conclusion}

In conclusion, treatment of Girolando donors with follicle stimulating hormone as described in this study did not significantly increase oocyte recovery (total or viable), in vitro embryo production, or pregnancy rate and, therefore, did not promote significant improvements for the in vitro production of embryos as a whole.

\section{References}

Adamiak, S. J., Mackie, K., Watt, R. G., Webb, R., \& Sinclair, K. D. (2005). Impact of nutrition on oocyte quality: Cumulative effects of body composition and diet leading to hyperinsulinemia in cattle. Biology of Reproduction, 73(5), 918-926. https://doi.org/10.1095/biolreprod.105.041483 
Adams, G., Jaiswal, R., Singh, J., \& Malhi, P. (2008). Progress in understanding ovarian follicular dynamics in cattle. Theriogenology, 69(1), 72-80. https://doi.org/10.1016/j.theriogenology.2007.09.026

Alves, B. G., Alves, K. A., Lúcio, A. C., Martins, M. C., Silva, T. H., Alves, B. G., ... Beletti, M. E. (2014). Ovarian activity and oocyte quality associated with the biochemical profile of serum and follicular fluid from Girolando dairy cows postpartum. Animal Reproduction Science, 146(3-4), 117-125. https://doi.org/ 10.1016/j.anireprosci.2014.02.019

Baruselli, P., Gimenes, L., \& Sales, J. (2007). Reproductive physiology of Bos taurus and Bos indicus females. Revista Brasileira de Reprodução Animal, 31(6).

Baruselli, P. S., de Sá Filho, M. F., Martins, C. M., Nasser, L. F., Nogueira, M. F., Barros, C. M., \& Bó, G. A. (2006). Superovulation and embryo transfer in Bos indicus cattle. Theriogenology, 65(1), 77-88. https://doi.org/10.1016/j.theriogenology.2005.10.006

Cavalieri, F. L. B., Morotti, F., Seneda, M. M., Colombo, A. H. B., Andreazzi, M. A., Emanuelli, I. P., \& Rigolon, L. P. (2017). Improvement of bovine in vitro embryo production by ovarian follicular wave synchronization prior to ovum pick-up. Theriogenology, 117, 57-60. https://doi.org/10.1016/j.theriogenology.2017.11.026

Chaubal, S. A., Ferre, L. B., Molina, J. A., Faber, D. C., Bols, P. E., Rezamand, P., ... Yang, X. (2007). Hormonal treatments for increasing the oocyte and embryo production in an OPU-IVP system. Theriogenology, 67(4), 719-728. https://doi.org/10.1016/j.theriogenology.2006.07.022

Chaubal, S. A., Molina, J. A., Ohlrichs, C. L., Ferre, L. B., Faber, D. C., Bols, P. E., ... Yang, X. (2006). Comparison of different transvaginal ovum pick-up protocols to optimise oocyte retrieval and embryo production over a 10-week period in cows. Theriogenology, 65(8), 1631-1648. https://doi.org/10.1016/ j.theriogenology.2005.07.020

Cole, J. B., \& Silva, M. V. G. B. D. (2016). Genomic selection in multi-breed dairy cattle populations. Revista Brasileira de Zootecnia, 45(4), 195-202. https://doi.org/10.1590/S1806-92902016000400008

da Silva, J. C. B., Ferreira, R. M., Maturana Filho, M., Naves, J. R., Santin, T., Pugliesi, G., \& Madureira, E. H. (2017). Use of FSH in two different regimens for ovarian superstimulation prior to ovum pick up and in vitro embryo production in Holstein cows. Theriogenology, 90, 65-73. https://doi.org/10.1016/ j.theriogenology.2016.11.016

da Silva, M. V. G. B., Martins, M. F., Cembranelli, M. A. R., Panetto, J. C. C., Paiva, L. C., Gonçalves, G. S., ... Faza, D. R. L. R. (2018). Programa de melhoramento genético da raça Girolando-Sumário de Touros-Resultado do Teste de Progênie Junho/2018. Embrapa Gado de Leite.

De Bem, T., Adona, P. R., Bressan, F. F., Mesquita, L. G., Chiaratti, M. R., Meirelles, F. V., \& Leal, C. (2014). The influence of morphology, follicle size and Bcl-2 and Bax transcripts on the developmental competence of bovine oocytes. Reproduction in Domestic Animals, 49(4), 576-583. https://doi.org/10.1111/rda.12325

De Roover, R., Feugang, J. M., Bols, P. E., Genicot, G., \& Hanzen, C. (2008). Effects of ovum pick-up frequency and FSH stimulation: A retrospective study on seven years of beef cattle in vitro embryo production. Reproduction in Domestic Animals, 43(2), 239-245. https://doi.org/10.1111/j.1439-0531. 2007.00873.x

Ferreira, R. M., Ayres, H., Chiaratti, M. R., Ferraz, M. L., Araujo, A. B., Rodrigues, C. A., ... Baruselli, P. S. (2011). The low fertility of repeat-breeder cows during summer heat stress is related to a low oocyte competence to develop into blastocysts. Journal of Dairy Science, 94(5), 2383-2392. https://doi.org/ $10.3168 /$ jds.2010-3904

Gimenes, L. U., Ferraz, M. L., Fantinato-Neto, P., Chiaratti, M. R., Mesquita, L. G., Sa Filho, M. F., ... Baruselli, P. S. (2015). The interval between the emergence of pharmacologically synchronized ovarian follicular waves and ovum pickup does not significantly affect in vitro embryo production in Bos indicus, Bos taurus, and Bubalus bubalis. Theriogenology, 83(3), 385-393. https://doi.org/10.1016/j.theriogenology.2014.09.030

Ginther, O., Siddiqui, M., Baldrighi, J., \& Araujo, E. (2017). An intraovarian mechanism that enhances the effect of an FSH surge on recovery of subordinate follicles in heifers. Domestic Animal Endocrinology, 59, 67-74. https://doi.org/10.1016/j.domaniend.2016.10.003

Ginther, O., Siddiqui, M., Baldrighi, J., \& Wolf, C. (2016). Systemic effect of follicle-stimulating hormone and intraovarian effect of the corpus luteum on complete regression vs recovery of regressing wave- 2 follicles in heifers. Domestic Animal Endocrinology, 55, 51-59. https://doi.org/10.1016/j.domaniend.2015.11.002 
Goodhand, K., Watt, R., Staines, M., Hutchinson, J., \& Broadbent, P. (1999). In vivo oocyte recovery and in vitro embryo production from bovine donors aspirated at different frequencies or following FSH treatment. Theriogenology, 51(5), 951-961. https://doi.org/10.101/S0093-691X (99) 00041-2

Goodhand, K. L., Staines, M. E., Hutchinson, J. S., \& Broadbent, P. J. (2000). In vivo oocyte recovery and in vitro embryo production from bovine oocyte donors treated with progestagen, oestradiol and FSH. Animal Reproduction Science, 63(3-4), 145-158. https://doi.org/10.1016/S0093-691X(99)00041-2

Khan, F., Pinaffi, F., Beg, M., \& Ginther, O. (2012). Unilateral ablation of follicles $\geq 4 \mathrm{~mm}$ leads to compensatory follicle response from the contralateral ovary in heifers. Theriogenology, 77(8), 1605-1614. https://doi.org/10.1016/j.theriogenology.2011.11.030

Kim, I., Son, D., Yeon, S., Choi, S., Park, S., Ryu, I., ... Yoon, J. (2001). Effect of dominant follicle removal before superstimulation of follicular growth, ovulation and embryo production in Holstein cows. Theriogenology, 55(4), 937-945. https://doi.org/10.1016/S0093-691X(01)00455-1

Lucy, M. (2007). The bovine dominant ovarian follicle. Journal of Animal Science, 85(Suppl. 13), E89-E99. https://doi.org/10.2527/jas.2006-663

Macaulay, A. D., Gilbert, I., Caballero, J., Barreto, R., Fournier, E., Tossou, P., ... Richard, F. J. (2014). The gametic synapse: RNA transfer to the bovine oocyte. Biology of Reproduction, 91(4), 90, 91-12. https://doi.org/10.1095/biolreprod.114.119867

Merton, J. S., de Roos, A. P., Mullaart, E., de Ruigh, L., Kaal, L., Vos, P. L., \& Dieleman, S. J. (2003). Factors affecting oocyte quality and quantity in commercial application of embryo technologies in the cattle breeding industry. Theriogenology, 59(2), 651-674. https://doi.org/10.1016/S0093-691X(02)01246-3

Oliveira Junior, G. A., Chud, T. C. S., Ventura, R. V., Garrick, D. J., Cole, J. B., Munari, D. P., ... da Silva, M. (2017). Genotype imputation in a tropical crossbred dairy cattle population. Journal of Dairy Science, 100(12), 9623-9634. https://doi.org/10.3168/jds.2017-12732

Oliveira, L. H., Sanches, C. P., Seddon, A. S., Veras, M. B., Lima, F. A., Monteiro, P. L. J., Jr., ... Sartori, R. (2016). Short communication: Follicle superstimulation before ovum pick-up for in vitro embryo production in Holstein cows. Journal of Dairy Science, 99(11), 9307-9312. https://doi.org/10.3168/ jds.2016-11306

Parrish, J. J. (2014). Bovine in vitro fertilization: in vitro oocyte maturation and sperm capacitation with heparin. Theriogenology, 81(1), 67-73. https://doi.org/10.1016/j.theriogenology.2013.08.005

Pontes, J., Silva, K., Basso, A., Rigo, A., Ferreira, C., Santos, G., ... Faifer, F. (2010). Large-scale in vitro embryo production and pregnancy rates from Bos taurus, Bos indicus, and indicus-taurus dairy cows using sexed sperm. Theriogenology, 74(8), 1349-1355. https://doi.org/10.1016/j.theriogenology.2010.06.004

Rahman, Z. A., Ibrahim, S. F., Osman, N. A., Jaffar, F. H. F., \& Osman, K. (2017). Effect of energy substrate dynamics on mitochondrial activity and oxidative stress levels of in vitro maturing bovine oocytes. Journal of Agricultural Science, 9(13), 14-23. https://doi.org/10.5539/jas.v9n13p14

Ratto, M. H., Peralta, O. A., Mogollon, G., Strobel, P., \& Correa, J. (2011). Transvaginal ultrasound-guided cumulus oocyte complexes aspiration and in vitro embryo production in suckled beef and lactating dairy cattle on pasture-based management conditions. Animal Reproduction Science, 129(1-2), 1-6. https://doi.org/10.1016/j.anireprosci.2011.10.001

Ribeiro, L., Rigolon, L., Cavalieri, F., Seko, M., Martínez, A., Ribeiro, M., .. De Conti, J. (2011). Oocyte recovery and in vitro production from cows stimulated with either FSH or eCG. Archivos de Zootecnia, 60[232(1)], 1021-1029.

Sastre, D., da Costa, N. N., de Sa, A. L., Conceicao, S. D., Chiaratti, M. R., Adona, P. R., ... Miranda Mdos, S. (2014). Expression of PLIN2 and PLIN3 during oocyte maturation and early embryo development in cattle. Theriogenology, 81(2), 326-331. https://doi.org/10.1016/j.theriogenology.2013.10.002

Sirard, M.-A., Desrosier, S., \& Assidi, M. (2007). In vivo and in vitro effects of FSH on oocyte maturation and developmental competence. Theriogenology, 68, S71-S76.

Sirard, M., \& Blondin, P. (1996). Oocyte maturation and IVF in cattle. Animal Reproduction Science, 42(1), 417-426. https://doi.org/10.1016/0378-4320(96)01518-7

Sovernigo, T. C., Adona, P. R., Monzani, P. S., Guemra, S., Barros, F., Lopes, F. G., \& Leal, C. (2017). Effects of supplementation of medium with different antioxidants during in vitro maturation of bovine oocytes on 
subsequent embryo production. Reproduction in Domestic Animals, 52(4), 561-569. https://doi.org/10.1111/ rda. 12946

Vieira, L. M., Rodrigues, C. A., Castro Netto, A., Guerreiro, B. M., Silveira, C. R., Moreira, R. J., ... Baruselli, P. S. (2014). Superstimulation prior to the ovum pick-up to improve in vitro embryo production in lactating and non-lactating Holstein cows. Theriogenology, 82(2), 318-324. https://doi.org/10.1016/j.theriogenology. 2014.04.013

Vieira, L. M., Rodrigues, C. A., Castro Netto, A., Guerreiro, B. M., Silveira, C. R. A., Freitas, B. G., ... Baruselli, P. S. (2016). Efficacy of a single intramuscular injection of porcine FSH in hyaluronan prior to ovum pick-up in Holstein cattle. Theriogenology, 85(5), 877-886. https://doi.org/10.1016/j.theriogenology. 2015.10.036

Vieira, L. M., Rodrigues, C. A., Mendanha, M. F., Sa Filho, M. F., Sales, J. N., Souza, A. H., ... Baruselli, P. S. (2014). Donor category and seasonal climate associated with embryo production and survival in multiple ovulation and embryo transfer programs in Holstein cattle. Theriogenology, 82(2), 204-212. https://doi.org/ 10.1016/j.theriogenology.2014.03.018

Wright, J. (1998). Photographic illustrations of embryo developmental stage and quality codes. Manual of the International Embryo Transfer Society.

Zhang, L., Jiang, S., Wozniak, P. J., Yang, X., \& Godke, R. A. (1995). Cumulus cell function during bovine oocyte maturation, fertilization, and embryo development in vitro. Molecular Reproduction and Development, 40(3), 338-344. https://doi.org/10.1002/mrd.1080400310

\section{Copyrights}

Copyright for this article is retained by the author(s), with first publication rights granted to the journal.

This is an open-access article distributed under the terms and conditions of the Creative Commons Attribution license (http://creativecommons.org/licenses/by/4.0/). 